\title{
Changes in the focus of European economic integration
}

\section{Axel A. Weber}

In the process of European integration, 2004 was undoubtedly one of the most memorable years. In May 2004 ten new member states joined the European Union. The eastward enlargement of the EU presents major political, institutional and economic challenges. Moreover, there is a very high probability that the process of eastward enlargement has not yet come to an end.

Does the enlargement of the EU imply a new shift in the focus of economic integration in Europe? At this juncture, it is difficult to give a clear answer to that question. The history of the EU has seen several such shifts. While in the early years of European integration the focus was on the goods markets, financial market integration has received more attention of late.

\section{EARLY STEPS TO EUROPEAN ECONOMIC INTEGRATION}

Some fifty years ago, a quite ordinary, yet pressing, cause gave rise to European economic integration. In the midst of reconstruction efforts, steelmakers - representing the backbone of several European economies were heading for a crisis of overproduction. The danger of competition being restricted by the re-erection of cartels was looming large, when Robert Schuman, then French Minister of Foreign Affairs, proposed the establishment of a European Coal and Steel Community. ${ }^{1}$ His proposal not only aimed at creating a unified market for coal and steel products; it also encompassed the bold idea that member states should surrender control over the coal and steel industry, which was still deemed strategically important, to a supranational body, the 'High Authority', later called the 'Commission'. Indeed, the transfer of sovereignty in specific areas from member states to newly created supranational institutions was to become a prominent feature of European integration. 
The idea of a single market for coal and steel was quickly extended to encompass the free movement of all products as well as free access to the means of production. The realization of a common market of this kind (i.e. an 'extended customs union') was the primary goal envisaged in the treaty establishing the European Economic Community (EEC), one of the Treaties of Rome.

By contrast, economic and monetary policy were considered merely a 'matter of common interest' and did not play a major role in the early years of European economic integration. In particular, monetary and exchange rate policies seemed to be sufficiently aligned by the Bretton Woods arrangements.

This assessment proved to be wrong, however. By the end of the 1960s, the Bretton Woods system, once characterized by Robert Mundell as the 'international disequilibrium system', ${ }^{2}$ started to creak under the strain of permanent external imbalances and speculative capital movements. Recurring balance of payments crises also posed a threat to the liberalization efforts in goods and capital markets, triggering calls for higher tariffs and stricter capital controls.

During those difficult times and after the customs union between EEC member countries had become fully effective in 1968, European governments acknowledged the need to gradually move towards a genuine economic and monetary union. As a first step recommended in the so-called Werner Report, European countries tried to stabilize the exchange rate movements between their currencies within a band narrower than the fluctuation margins established by the Bretton Woods system. As we all know, this effort - the 'snake in the tunnel' as well as its successor, the snake eventually failed due to a lack of willingness to align economic and monetary policies within Europe.

In 1979, a new start was made through the establishment of the European Monetary System (EMS). Although the European Monetary System was intended to promote macroeconomic stability among participating countries, the original aim of the Werner Plan - the introduction of economic and monetary union (EMU) by 1980 - had to be abandoned.

In the mid-1980s fresh impetus for the process of European economic integration came from the White Paper in which the Commission proposed the creation of a single European market, allowing the free movements of goods, services, people and capital by the end of 1992. This final implementation of the common market originally envisioned in the Treaties of Rome was subsequently codified in the Single European Act.

However, in a setting where capital markets are completely integrated and, in addition, exchange rates are pegged but adjustable - as was basically the case in the EMS - individual countries cannot pursue independent 
monetary policies. (Unfortunately, Europeans had to learn this lesson the hard way during the crisis of the EMS). Thus, along with the realization of the single market, monetary integration was revived as well. Indeed, based on the seminal Delors Report, a roadmap to EMU was eventually enshrined in the Maastricht Treaty.

The prominence that financial market integration received after the adoption of the Single European Act reflects technological progress as well as market and policy developments in this field. Financial market deregulation and the liberalization of cross-border capital movements featured prominently on the international agenda during the 1980s and 1990s as the virtues of integrated financial markets became widely accepted.

Market integration is the precondition for efficient risk-sharing across countries as well as across market segments; in fact, standard economic theory tells us that only complete markets allow for a perfect hedge. A second gain is the superior allocation of capital in integrated financial markets, creating the potential for enhanced growth. Moreover, barrier-free markets promote competition, giving a further boost to welfare. In addition, debtors - governments as well as the corporate sector - can gain in an integrated market from reduced bond spreads, while investors gain from the expanded choice of assets.

Several Directives aimed at promoting competition and creating a level playing field in the market for financial services have come into effect. More recently, the Financial Services Action Plan (FSAP) was adopted in 1999. It is to date the most ambitious initiative for integrating capital markets and achieving a single market for financial services in the EU. Meanwhile almost all 42 FSAP measures have been converted into Directives and Communications. Nonetheless, implementation in national legal systems is still outstanding in many areas. ${ }^{3}$

\section{ESTABLISHMENT OF MONETARY UNION}

The launch of EMU had repercussions on the international financial markets in general and on the integration of European financial markets in particular. Indeed, the final stage of the establishment of EMU in 1999 saw the creation of a new currency, which, if only because of the economic weight of the currency area concerned, had far greater significance than the event itself might lead one to expect. As an investment and reserve currency, the euro now ranks just after the dollar.

The new currency regime has brought about noticeable changes in the level and pattern of cross-border capital flows. In the case of Germany, the importance of portfolio investment in other euro area countries, for 
example, has seen a particular increase while, conversely, large amounts of capital have flowed into Germany from countries not participating in monetary union. Particularly at the start of monetary union there was a remarkably strong momentum among German investors towards the internationalization and diversification of their portfolios. Since the start of EMU their net purchases of foreign securities have amounted to nearly EUR 700 billion. Parallel to the increase in German investment abroad, nonresidents have invested about EUR 650 billion in German securities. These trends have contributed significantly to the integration of financial markets in Europe.

From the central bank's point of view, the money market is of vital importance. Only in sufficiently integrated money markets can the central bank manage the money supply in an efficient manner, that is without having to analyse liquidity separately for each market and being able to auction off money without regard to the counterpart.

Fortunately, we can observe near-perfect integration in the overnight unsecured market, where the dispersion of spreads oscillates around two basis points. The repo market exhibits fewer signs of integration, though significant progress has been made over the past few years. The remaining discrepancies are mainly due to differences in market practices, legislation, regulation and the fragmentation of the infrastructure in the euro area, all of which are currently in the process of being harmonized.

With regard to the market for short-term debt derivatives we observe a large, liquid and well-integrated market. Rates converged quickly after the introduction of the euro and since mid-1999 their cross-sectional standard deviation for either one-year or ten-year swaps has not exceeded a single basis point on any one day.

Other financial markets also exhibit strong integration tendencies, although they remain less integrated than the money market. As one would expect, retail banking reveals the most pronounced home bias, largely due to non-regulatory barriers and cultural differences, such as diverse preferences for types of credit. The euro area government bond market has shown a distinct trend towards unification, that is yields can be observed to be driven increasingly by common news, rather than by purely local risk factors.

An enlightening example of the introduction of the euro fostering integration is provided by the portfolio structure of mutual funds in Germany. Traditionally exhibiting a strong home bias, they reveal evidence of a trend towards diversification prior to the introduction of the euro. In December 1998, German mutual funds for the first time held more stocks of foreign provenance than of domestic issuers. A similar pattern can be observed in the composition of bond holdings. The share of securities issued by foreign entities has been rising steadily since 1996 . 
The observed assimilation in different financial markets needs to be analysed in greater detail, since convergence effects are not due to enhanced integration only. Account needs to be taken of at least three other factors. First, the exchange rate premium has vanished by definition in the single currency area. Furthermore, economic and monetary policies have converged throughout the euro area and, finally, governments face similar restrictions in their fiscal policies as a consequence of the Stability and Growth Pact.

The concluding message is bright: financial markets within the euro area are already widely integrated, albeit to varying degrees. The money market - in particular the unsecured overnight lending market - is almost perfectly integrated, allowing the European System of Central Banks (ESCB) to conduct an efficient monetary policy. Further integration in other financial markets can be expected when all the FSAP measures have been fully implemented. ${ }^{4}$

\section{EU ENLARGEMENT}

European economic integration not only entails the deepening of economic relationships between a given set of countries but has at the same time a regional component. The first group of Central and Eastern European countries acceded (together with Cyprus and Malta) to the European Union on 1 May 2004. Other countries will follow in the years to come.

This so-called eastern enlargement is of special interest, since the new member countries (with the exception of Cyprus and Malta) have gone through a fundamental social and economic transformation. Within a decade they have caught up with the process of economic integration which in Western Europe started more than fifty years ago with the European Coal and Steel Community.

Orientation to and integration into the European Union has been the key element of economic transformation from the very beginning. In the first half of the 1990s political concern focused on macroeconomic stabilization and the timing and sequencing of external liberalization. The eight countries which now participate in the European single market quickly removed the impediments to current account transactions and redirected their trade to Western Europe. Today their share of intra-EU trade exceeds 50 per cent and is thus comparable with or even exceeds the ratio in the older EU countries.

In contrast to current account convertibility, a greater variation can be observed in the approaches to capital liberalization. Some countries opted for a gradual procedure and initially only removed restrictions on inflows 
of foreign direct investment and other long-term capital. Controls on short term capital inflows which are considered to be more speculative in nature and are more susceptible to speculative attacks were relaxed at a later stage. Other countries deregulated the entire capital account in a 'big bang' and thereby increased the pressure on the domestic economy to adjust to a highly competitive environment.

Despite these differences in the intermediate period, all the new member states have now introduced the acquis communautaire of the European Union with, at most, marginal temporary arrangements. This contrasts with former enlargements when far-reaching exceptions, especially in capital account liberalization, were granted to countries such as Greece, Portugal or Spain.

Today, the focus of economic integration in the new member states is more or less the same as in the rest of the European Union - the development and integration of the financial markets and further progress in monetary integration. Markets apparently expect most of the Central and Eastern European 'pre-ins' to adopt the euro within the next decade. This is underlined by the convergence of long-term interest rates vis-à-vis the average euro-area rate. Three countries, namely Estonia, Lithuania and Slovenia, have already joined ERM II, which is an important instrument for the coordination of the exchange rate policy within the Eurosystem.

Despite the economic convergence achieved so far, however, there are still major differences between the new and the old member states. The present income differences - which are still considerable - indicate that real convergence is not yet complete and will entail further adjustments in relative prices and real exchange rates. Their development will need to be observed closely and reviewed carefully. However, the key issue in Central and Eastern Europe is the need to develop and strengthen further the financial sector. Especially with regard to the single financial market, it is essential to further financial intermediation and to establish the efficiency of capital markets which are at the moment only at an early stage of development.

Let me conclude this review of enlargement with some remarks on future prospects. European integration is a process which will not be terminated in the foreseeable future. The next challenge is already waiting in the wings: Bulgaria and Romania are negotiating with a view to acceding in 2007, Turkey has the official status of an accession candidate and other countries, especially from the Western Balkans, have expressed their wish to accede to the European Union.

This is not the place to discuss the likely future shape of the European Union nor to assess the current progress in political and economic reform by individual countries. Without doubt, however, further enlargement will at the same time make the European Union more heterogeneous, and 
constant efforts will be needed to ensure that it continues to function smoothly. This said, however, the process of integration can be expected to benefit all European countries and thus enhance welfare across the entire continent.

\section{NOTES}

1. See Fontaine (2000).

2. See Mundell (1961).

3. See Deutsche Bundesbank (2004).

4. See European Central Bank (2004).

\section{REFERENCES}

Deutsche Bundesbank (2004), 'Regulation of the European securities markets', Monthly Report, July, pp. 33-48.

European Central Bank (2004), 'Developments in the EU framework for financial regulation, supervision and stability', Monthly Bulletin, November, 81-93.

Fontaine, Pascal (2000), A New Idea for Europe - The Schuman Declaration 1950-2000, European Commission.

Mundell, Robert A. (1961), 'The International Disequilibrium System', Kyklos, 14, pp. 153-72. 